DOI: $10.15193 /$ zntj/2017/110/175

\author{
TERESA WITCZAK, ANNA STĘPIEŃ, KAROLINA PYCIA, \\ MARIUSZ WITCZAK, AGATA BEDNARZ, MIROSŁAW GRZESIK
}

\title{
WPLYW MODYFIKACJI CHEMICZNEJ SKROBI I STOPNIA HYDROLIZY NA IZOTERMY SORPCJI PARY WODNEJ HYDROLIZATÓW
}

Streszczenie

W pracy badano właściwości sorpcyjne maltodekstryn uzyskanych w reakcji enzymatycznej hydrolizy skrobi ziemniaczanej natywnej, acetylowanej oraz fosforanu diskrobiowego. Określono również wpływ uzyskanego stopniu scukrzenia (DE 6,11,16) na higroskopijność produktów. Izotermy sorpcji wyznaczono metodą statyczną w środowisku o aktywności wody $0 \div 0,903 \mathrm{w}$ temp. $25^{\circ} \mathrm{C}$. Do opisu izoterm zastosowano trzy modele matematyczne. Stwierdzono, że czteroparametrowy model Pelega umożliwił prezentację danych eksperymentalnych w pełnym badanym zakresie aktywności wody, podczas gdy wykorzystanie modeli BET i GAB wymagało ograniczenia danych. Wszystkie uzyskane krzywe charakteryzowały się sigmoidalnym kształtem, charakterystycznym dla izoterm typu II według klasyfikacji Brunauera i wsp. W zakresie adsorpcji mono- i wielowarstwowej badane hydrolizaty wykazywały zbliżone właściwości. Największe różnice w równowagowej zawartości wilgoci zaobserwowano przy aktywności wody większej od 0,7. Stwierdzono, że właściwości sorpcyjne badanych produktów uwarunkowane były głównie stopniem scukrzenia, natomiast modyfikacja chemiczna skrobi wpłynęła znacznie na ilość pochłoniętej wilgoci tylko w środowisku o wysokiej aktywności wody.

Słowa kluczowe: maltodekstryny, równoważnik glukozowy, skrobie modyfikowane, izotermy sorpcji

\section{Wprowadzenie}

W przemyśle spożywczym szeroko wykorzystywanymi substancjami pomocniczymi są hydrolizaty skrobi, które dzięki swoim właściwościom funkcjonalnym pozwalają na uzyskanie produktów spożywczych o odpowiednich cechach jakościowych.

Dr inż. T. Witczak, mgr inż. A. Stępień, dr hab. inż. M. Witczak, mgr inż. A. Bednarz, prof. dr hab. M. Grzesik,. Katedra Inżynierii i Aparatury Przemystu Spożywczego, Wydz. Technologii Żywności, Uniwersytet Rolniczy w Krakowie, ul. Balicka 122, 30-149 Kraków, dr inż. K. Pycia, Katedra Ogólnej Technologii Żywności i Żywienia Człowieka, Wydz. Biologiczno-Rolniczy, Uniwersytet Rzeszowski, ul. Zelwerowicza 4, 35-601 Rzeszów.Kontakt: t.witczak@ur.krakow.pl 
Zalicza się do nich maltodekstryny [24], które otrzymywane są głównie w wyniku częściowej enzymatycznej hydrolizy skrobi. W zależności od warunków prowadzenia procesu oraz formy natywnej biopolimeru uzyskuje się produkty o różnym stopniu hydrolizy, przy czym ich równoważnik glukozowy DE przyjmuje wartość niższą od 20. Stanowią one mieszaninę węglowodanów wysoko- i niskocząsteczkowych, w wyniku czego nawet przy identycznej wartości DE mogą charakteryzować się odmiennymi właściwościami fizycznymi $[22,26]$. Maltodekstryny o wysokiej wartości równoważnika glukozowego cechuje m.in. dobra rozpuszczalność, higroskopijność oraz duża słodkość, przy jednoczesnym zmniejszeniu lepkości roztworów z ich udziałem i obniżeniu punktu zamarzania. Wykorzystywane są jako środki zagęszczające, wypełniające, stabilizujące smak i zapach oraz substancje zapobiegające krystalizacji sacharozy w produktach wysoko słodzonych [27, 30].

Maltodekstryny odgrywają również ważną rolę jako substancje pomocnicze w mikrokapsułkowaniu metodą rozpyłową oraz w suszeniu rozpyłowym żywności o dużej zawartości cukrów prostych i kwasów organicznych $[6,11,20]$. Dzięki ich zastosowaniu możliwe jest wyeliminowanie licznych niekorzystnych zjawisk, które w dalszej kolejności wpływają na wydajność procesu oraz jakość produktu końcowego. Obecność maltodekstryn powoduje wzrost temperatury przemiany szklistej amorficznych proszków, co chroni je przed przemianami fizycznymi, których konsekwencją są zjawiska aglomeryzacji, zlepiania czy zbrylania. Produkty takie pozostają bardzo wrażliwe na zmiany temperatury i wilgotności względnej otoczenia, dlatego parametry te muszą być pod ciągłą kontrolą w trakcie transportu i przechowywania.

W przypadku artykułów spożywczych przewidywanie niekorzystnych przemian o charakterze fizycznym, chemicznym oraz mikrobiologicznym możliwe jest na podstawie znajomości stopnia dostępności wody. Jednym z narzędzi wykorzystywanych w tym celu są izotermy sorpcji, które w stałej temperaturze i przy stałym ciśnieniu całkowitym przedstawiają zależność pomiędzy ilością zaadsorbowanej wody i aktywnością wody [2]. Zjawisku adsorpcji pary wodnej w biopolimerach towarzyszą zmiany strukturalne matrycy związane $\mathrm{z}$ procesami pęcznienia, natomiast dostępność grup hydrofilowych w dużej mierze uzależniona jest od konformacji oraz budowy cząsteczek. Właściwości sorpcyjne skrobi uwarunkowane są występowaniem w ziarnach form amorficznych oraz krystalicznych. Struktury amorficzne w dużo większym stopniu wykazują skłonności do pochłaniania cząsteczek wody w stosunku do krystalicznych, dla których zjawisko to zachodzi jedynie na powierzchni kryształów. W miarę wzrostu aktywności wody następuje uplastycznienie struktur amorficznych, dzięki czemu grupy polarne stają się bardziej dostępne dla cząsteczek wody [3].

Izotermy adsorpcji wody uzyskane dla skrobi natywnej różnego pochodzenia botanicznego mają kształt sigmoidalny $[3,16,23]$, charakterystyczny dla izoterm zaliczanych do typu II według klasyfikacji Brunauera i wsp. [4]. Taki sam mechanizm 
wiązania wody wykazują skrobie poddane modyfikacji chemicznej $[9,18]$, przy czym, jak stwierdzili Fornal i wsp. [9], proces modyfikacji prowadzi do zwiększenia ich higroskopijności w porównaniu ze skrobią natywną.

Właściwości sorpcyjne maltodekstryn związane są ze stopniem scukrzenia, niezależnie jednak od wartości DE ich izotermy mają przebieg sigmoidalny, charakterystyczny dla biopolimerów $[17,25,28]$. Uzyskany w wyniku hydrolizy skrobi wzrost udziału grup hydroksylowych powoduje zwiększenie higroskopijności maltodekstryn. Największe różnice występują przy wysokich wartościach aktywności wody, kiedy to rozpoczynają się zjawiska rozpuszczania węglowodanów o niższej masie cząsteczkowej [17, 28]. Castri i wsp. [7] porównali pięć maltodekstryn różniących się stopniem scukrzenia i wykazali, że maltodekstryna o najniższej wartości równoważnika glukozowego miała przebieg izotermy zbliżony do typu III według klasyfikacji Brunauera i wsp. [4]. Przypadek ten charakteryzuje się brakiem wyraźnie zaznaczonego obszaru adsorpcji monowarstwowej, co świadczy o zmianie mechanizmu pochłaniania wody. Maltodekstryna ta wykazała również najwyższą higroskopijność przy aktywności wody większej od 0,8 . Dowodzi to, że jednoznaczne określenie zmiany struktury skrobi oraz stopnia jej degradacji zarówno w procesach hydrolizy enzymatycznej, jak i innych modyfikacji, jest skomplikowane, co utrudnia przewidywanie ich właściwości fizykochemicznych.

Właściwości sorpcyjne skrobi natywnej i modyfikowanej oraz maltodekstryn o różnym stopniu scukrzenia zostały szeroko omówione w literaturze przedmiotu [3, 9 , $18,17,25,28]$. Brak jest natomiast informacji na temat zdolności sorpcji pary wodnej przez hydrolizaty skrobi modyfikowanej.

Celem niniejszej pracy było wyznaczenie izoterm sorpcji pary wodnej przez maltodekstryny uzyskane ze skrobi ziemniaczanej natywnej oraz skrobi ziemniaczanej stabilizowanej i sieciowanej. Mając na uwadze, że materiały te łączą w sobie właściwości skrobi i cukrów, w ramach badań podjęto próbę określenia wpływu rodzaju modyfikacji materiału pierwotnego oraz stopnia scukrzenia hydrolizatów na ich właściwości sorpcyjne.

\section{Material i metody badań}

W badaniach użyto hydrolizatów skrobi ziemniaczanej (SZ), skrobi acetylowanej (E1420) oraz fosforanu diskrobiowego (E1412) o trzech różnych wartościach równoważnika glukozowego DE: 6, 11 i 16. Materiałem wyjściowym były handlowe preparaty pochodzące z Wielkopolskiego Przedsiębiorstwa Przemysłu Ziemniaczanego S.A. w Luboniu. Reakcję hydrolizy prowadzono w reaktorze okresowym w temp. $85{ }^{\circ} \mathrm{C}$, wykorzystując enzym amylolityczny o handlowej nazwie BAN 480L (Novozymes, Dania). Czas reakcji niezbędny do uzyskania żądanej wartości równoważnika glukozowego wyznaczony został eksperymentalnie dla każdego rodzaju skrobi [21]. W dal- 
szej kolejności hydrolizaty rozlewano do szalek Petriego i zamrażano w temp. $-12{ }^{\circ} \mathrm{C}$ $\mathrm{w}$ ciągu $24 \mathrm{~h}$. Tak przygotowane preparaty poddawano suszeniu sublimacyjnemu w liofilizatorze typu Alpha 1-2LD plus Christ (Wielka Brytania) przy ciśnieniu $7 \mathrm{~Pa}$ $(21 \mathrm{~h}$ ), a następnie dosuszano przez $1,5 \mathrm{~h}$. Wysuszony hydrolizat po rozdrobnieniu w moździerzu przesiewano przez sita o średnicy $200 \mu \mathrm{m}$, a następnie przechowywano przez dwa tygodnie w eksykatorze nad $\mathrm{P}_{2} \mathrm{O}_{5} \mathrm{w}$ celu dosuszenia.

Do wyznaczenia izoterm sorpcji zastosowano metodę statyczno-eksykatorową. Odważoną masę proszków (ok. $1 \mathrm{~g}$ ) przetrzymywano w szczelnych naczyniach nad nasyconymi roztworami soli (jako czynnikami higrostatycznymi) w środowisku o wilgotności względnej $0,113 \div 0,903$. W celu ochrony próbek przed rozwojem mikroorganizmów w eksykatorach o aktywności wody powyżej 0,75 umieszczano tymol. Próbki przechowywano w temp. $25^{\circ} \mathrm{C}$ aż do ustalenia się stanu równowagi (ok. 6 tygodni), stwierdzonego na podstawie niezmiennej masy podczas pomiarów kontrolnych. Badania wykonano w trzech powtórzeniach.

Dane eksperymentalne aproksymowano za pomocą trzech modeli matematycznych:

$$
\begin{aligned}
- & \text { BET [5]: } & u & =\frac{u_{m} \cdot C \cdot a_{W}}{\left(1-a_{W}\right) \cdot\left(1+(C-1) \cdot a_{W}\right)} \\
- & \text { GAB }[1,8,12]: & u & =\frac{u_{m} \cdot C \cdot K \cdot a_{W}}{\left(1-K \cdot a_{W}\right) \cdot\left(1-K \cdot a_{W}+C \cdot K \cdot a_{W}\right)} \\
- & \text { Peleg [19]: } & u & =A \cdot a_{W}^{D}+B \cdot a_{W}^{E}
\end{aligned}
$$

gdzie: $A, B, C, D, E, k$ - parametry modeli, $a_{w}$ - aktywność wody, $u$ - wyznaczona eksperymentalnie wilgotność równowagowa (g/g s.s.) $u_{m}$ - zawartość wody w monowarstwie (g/g s.s.)

Obliczenia wykonano z użyciem modułu estymacji nieliniowej programu Statistica 9.0. (Statsoft, Inc., USA) z wykorzystaniem algorytmu Levenberga-Marquardta. Dopasowanie zastosowanych modeli do danych eksperymentalnych oceniono na podstawie wartości współczynnika determinacji $\mathrm{R}^{2} \mathrm{i}$ średniego błędu kwadratowego (RMS) [10].

W celu oceny wpływu stopnia hydrolizy oraz rodzaju modyfikacji chemicznej skrobi na parametry równań opisujących izotery sorpcji stosowano analizę wariancji dla efektów głównych na poziomie istotności równym 0,05 .

\section{Wyniki i dyskusja}

Izotermy sorpcji pary wodnej przez hydrolizaty skrobiowe przedstawiono na rys. 1. Uzyskane krzywe miały sigmoidalny kształt odpowiadający typowi II izoterm według klasyfikacji Brunauera i wsp. [4]. Sigmoidalny przebieg izoterm, charakterystyczny dla amorficznych materiałów białkowych i skrobiowych, wiąże się z występowa- 
niem trzech zakresów adsorpcji: monomolekularnej $\left(a_{w}<0,3\right)$, wielowarstwowej $(0,3<$ $\left.a_{w}<0,7\right)$ i kondensacji kapilarnej $\left(a_{w}>0,7\right)$. Niezależnie od rodzaju pierwotnej modyfikacji hydrolizaty o najniższym stopniu hydrolizy DE 6 charakteryzowały się najwyższymi wartościami równowagowej zawartości wilgoci w obszarze pierwszego i drugiego zakresu adsorpcji. Przy aktywności wody ok. 0,7, w punkcie przegięcia krzywych, zaobserwowano odwrócenie tendencji do chłonięcia wilgoci, w rezultacie czego w ostatnim zakresie $a_{w}$ najwyższą higroskopijność wykazywały proszki o najwyższej wartości DE. Wzrost równowagowej zawartości wody wraz ze stopniem scukrzenia maltodekstryny potwierdzają badania Saavedra-Leos i wsp. [26], Roosa [25] oraz Stępień i wsp. [28]. Najbardziej zauważalny wpływ stopnia hydrolizy na właściwości sorpcyjne przy $a_{w}>0,7$ odnotowano w przypadku maltodekstryn uzyskanych ze skrobi ziemniaczanej natywnej.

Zaobserwowano, że niezależnie od stopnia hydrolizy równowagowa zawartość wody badanych proszków w I i II zakresie adsorpcji była zbliżona, a największą higroskopijność wykazała maltodekstryna na bazie skrobi ziemniaczanej natywnej (rys. 1). Istotne różnice pod względem ilości zaadsorbowanej wody odnotowano przy aktywności wody większej od 0,8 . W przypadkach najniższego stopnia scukrzenia w III zakresie adsorpcji największą higroskopijność wykazał hydrolizat fosforanu diskrobiowego (E1420) (rys. 1). Maltodekstryny o niskim stopniu scukrzenia w dużej mierze zachowują właściwości materiału pierwotnego. Usieciowane cząsteczki fosforanu diskrobiowego wykazują duże powinowactwo do wiązania wody [14], można zatem przyjąć, że cecha ta została zachowana przy niskim stopniu hydrolizy tej skrobi. Takie właściwości wykazał hydrolizat skrobi acetylowanej (E1420) o DE 11, natomiast w przypadku hydrolizatów o DE16 największą równowagową zawartością wody charakteryzowały się produkty otrzymane na bazie skrobi natywnej. Uzyskane wyniki wskazują, że w następstwie przeprowadzonej hydrolizy omawianych skrobi otrzymano mieszaninę produktów o różnym składzie cukrowym, który zależał od czasu prowadzenia reakcji hydrolizy oraz rodzaju chemicznej modyfikacji skrobi [22]. Maltodekstryny, które wykazały największą równowagową zawartość wilgoci przy aktywności wody powyżej 0,8 , musiały zatem w swoim składzie zawierać najwięcej cukrów niskocząsteczkowych [10].

Izotermy sorpcji pary wodnej opisane zostały za pomocą trzech modeli matematycznych: BET, GAB i Pelega. Wyznaczone wartości parametrów wraz z obliczonymi wartościami współczynnika determinacji i średniego błędu kwadratowego przedstawiono w tab. 1 . W pełnym badanym zakresie $a_{w}$ do przedstawienia danych sorpcyjnych zastosowano model Pelega, a uzyskane wartości wykładników potwierdzają sigmoidalny przebieg izoterm sorpcji [19]. 

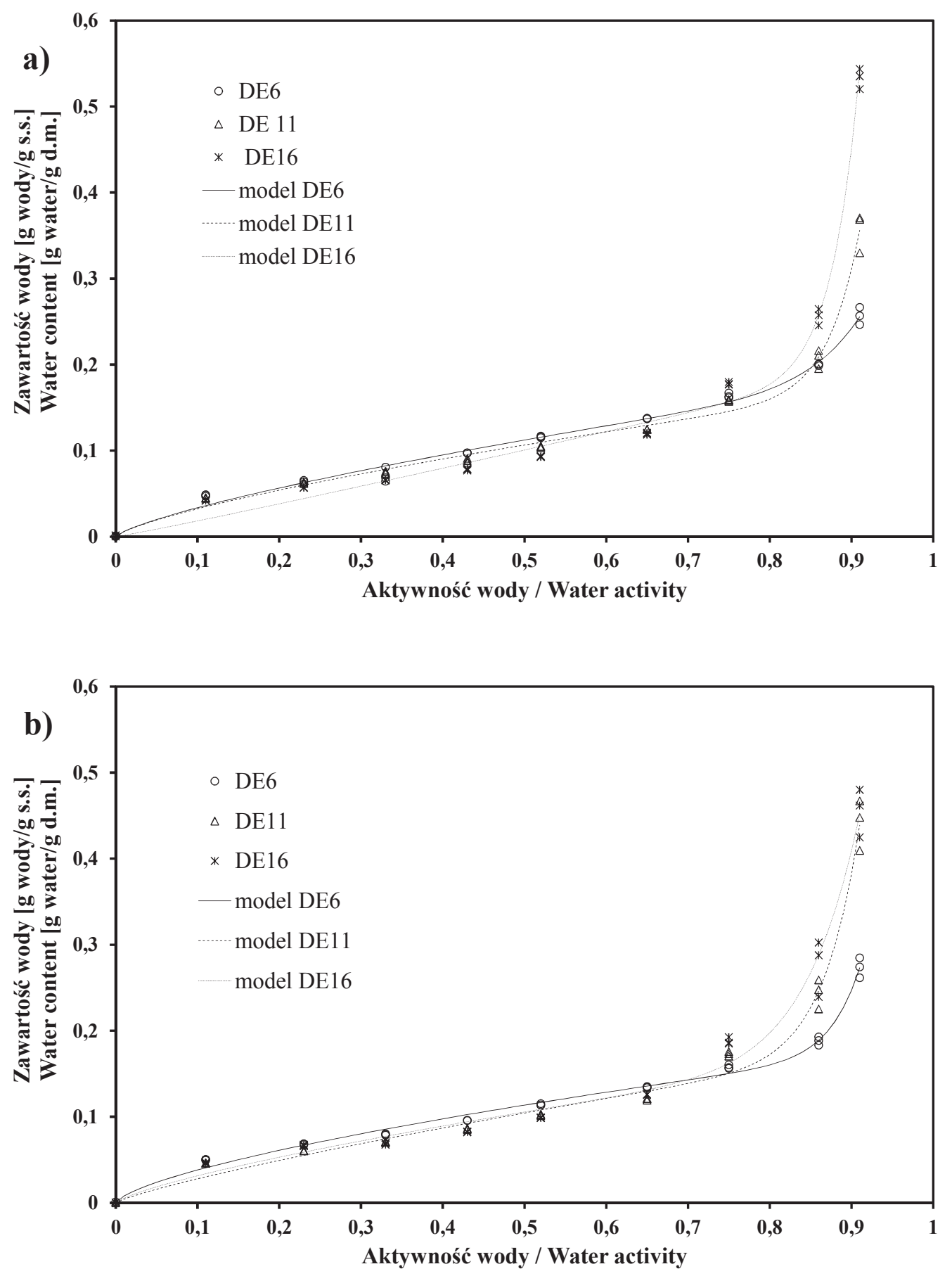


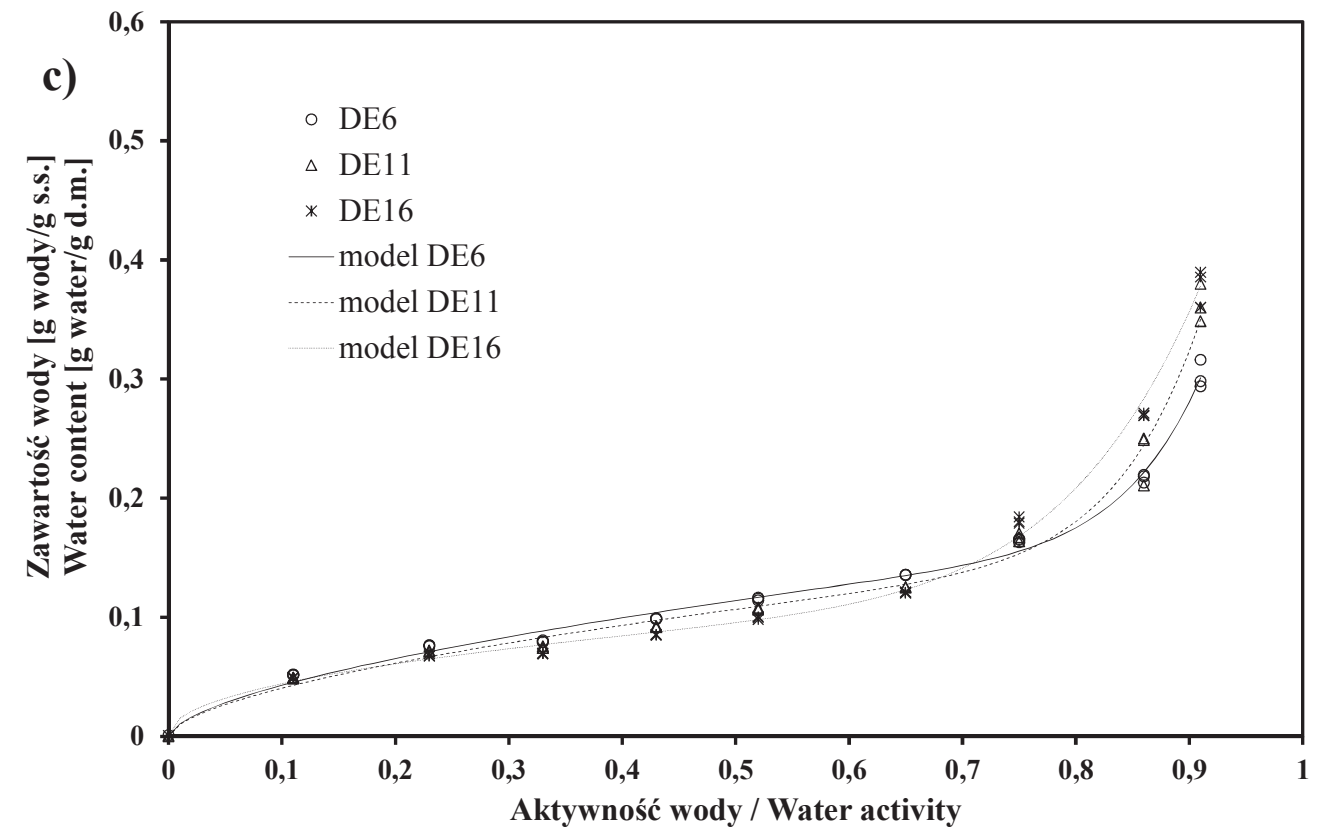

Rys. 1. Wpływ stopnia scukrzenia na właściwości sorpcyjne hydrolizatów skrobi: a) skrobia ziemniaczana natywna, b) skrobia modyfikowana E1412, c) skrobia modyfikowana E1420. Punkty doświadczalne i wyznaczone z modelu Pelega

Fig. 1. Effect of dextrose equivalent on sorption properties of starch hydrolysates: a) native potato starch; b) E1412 modified starch; c) E1420modified starch. Experimental points and points calculated from Peleg model

Zawartość wody w monowarstwie $u_{m}$, rozumiana jako ilość wilgoci silnie związanej w centrach aktywnych na powierzchni materiału, ma istotne znaczenie w przypadku przewidywania optymalnych warunków przechowywania. Według Karela [13] wartość $u_{m}$ produktów spożywczych waha się w granicach $0,04 \div 0,11 \mathrm{~g}$ wody na $1 \mathrm{~g}$ suchej substancji. Wartości $u_{m}$ uzyskane przez badane próbki hydrolizatów skrobi mieściły się w tym przedziale. Zawartość wody w monowarstwie wyznaczona z modelu BET we wszystkich próbkach była nieznacznie niższa niż w przypadku zastosowania modelu GAB. Zróżnicowanie pojemności monowarstwy w zależności od użytego modelu związane jest z założeniami teorii adsorpcji. Według Timmermann i wsp. [29] wartość $u_{m}$ wyznaczona na podstawie równania GAB jest zazwyczaj o ok. $15 \%$ wyższa niż ta otrzymana z równania BET.

Zaobserwowano, że na zróżnicowanie pojemności monowarstwy znacząco wpływa stopień hydrolizy skrobi $(\mathrm{p}=0,003)$, podczas gdy wpływ rodzaju modyfikacji chemicznej był statystycznie nieistotny $(\mathrm{p}=0,4)$. Wszystkie badane proszki wykazywały zmniejszenie wartości $u_{m}$ wraz ze wzrostem wartości DE. 
Tabela 1. Parametry modeli sorpcyjnych hydrolizatów skrobi natywnej i modyfikowanej

Table 1. Parameters of sorption models for native and modified starch hydrolysates

\begin{tabular}{|c|c|c|c|c|c|c|c|c|c|}
\hline \multirow{2}{*}{$\begin{array}{c}\text { Parametr } \\
\text { Parameter }\end{array}$} & \multicolumn{9}{|c|}{ Rodzaj hydrolizatu / Type of hydrolysate } \\
\hline & $\begin{array}{c}\text { SZ } \\
\text { DE6 }\end{array}$ & $\begin{array}{c}\text { SZ } \\
\text { DE11 }\end{array}$ & $\begin{array}{c}\text { SZ } \\
\text { DE16 }\end{array}$ & $\begin{array}{c}\text { E1412 } \\
\text { DE6 }\end{array}$ & $\begin{array}{c}\text { E1412 } \\
\text { DE11 }\end{array}$ & $\begin{array}{c}\text { E1412 } \\
\text { DE16 }\end{array}$ & $\begin{array}{c}\text { E1420 } \\
\text { DE6 }\end{array}$ & $\begin{array}{c}\text { E1420 } \\
\text { DE11 }\end{array}$ & $\begin{array}{c}\text { E1420 } \\
\text { DE16 }\end{array}$ \\
\hline \multicolumn{10}{|c|}{ PELEG } \\
\hline A & 0,321 & 1,770 & 4,295 & 1,094 & 1,874 & 1,069 & 0,499 & 0,648 & 0,538 \\
\hline $\mathrm{B}$ & 14,77 & 23,66 & 26,50 & 25,08 & 20,62 & 13,99 & 13,70 & 12,61 & 7,89 \\
\hline $\mathrm{D}$ & 0,189 & 0,178 & 0,210 & 0,182 & 0,184 & 0,178 & 0,174 & 0,162 & 0,129 \\
\hline $\mathrm{E}$ & 0,749 & 0,740 & 1,057 & 0,679 & 0,820 & 0,753 & 0,607 & 0,602 & 0,464 \\
\hline $\mathrm{R}^{2}$ & 0,9913 & 0,9911 & 0,9878 & 0,9938 & 0,9883 & 0,9843 & 0,9943 & 0,9901 & 0,9950 \\
\hline RMS & 10,75 & 9,05 & 18,64 & 7,57 & 13,32 & 13,26 & 6,59 & 7,80 & 5,60 \\
\hline $\begin{array}{c}\text { Zakres } a_{w} \\
a_{w} \text { range }\end{array}$ & \multicolumn{9}{|c|}{$0 \div 0,903$} \\
\hline \multicolumn{10}{|c|}{ BET } \\
\hline $\mathrm{u}_{\mathrm{m}}$ & 0,0570 & 0,0525 & 0,0460 & 0,0567 & 0,0499 & 0,0486 & 0,0575 & 0,0534 & 0,0489 \\
\hline $\mathrm{C}$ & 20,77 & 28,76 & 40,92 & 31,80 & 32,52 & 63,22 & 42,69 & 49,71 & 116,33 \\
\hline $\mathrm{R}^{2}$ & 0,9571 & 0,9928 & 0,9964 & 0,9970 & 0,9992 & 0,9628 & 0,9715 & 0,9696 & 0,9634 \\
\hline RMS & 1,78 & 2,44 & 1,80 & 1,49 & 0,79 & 5,87 & 5,27 & 5,28 & 5,22 \\
\hline $\begin{array}{c}\text { Zakres } \mathrm{a}_{\mathrm{w}} \\
\mathrm{a}_{\mathrm{w}} \text { range }\end{array}$ & \multicolumn{9}{|c|}{$0 \div 0,529$} \\
\hline \multicolumn{10}{|c|}{ GAB } \\
\hline $\mathrm{u}_{\mathrm{m}}$ & 0,0788 & 0,0627 & 0,0510 & 0,0788 & 0,0536 & 0,0523 & 0,0687 & 0,0576 & 0,0507 \\
\hline $\mathrm{C}$ & 11,16 & 18,83 & 21,39 & 14,86 & 26,95 & 35,64 & 25,19 & 41,51 & 81,75 \\
\hline $\mathrm{k}$ & 0,731 & 0,819 & 0,936 & 0,700 & 0,910 & 0,946 & 0,799 & 0,880 & 0,946 \\
\hline $\mathrm{R}^{2}$ & 0,9886 & 0,9949 & 0,9932 & 0,9958 & 0,9893 & 0,9774 & 0,9957 & 0,9825 & 0,9945 \\
\hline RMS & 3,77 & 2,26 & 3,78 & 3,32 & 3,77 & 6,14 & 3,63 & 5,39 & 5,02 \\
\hline $\begin{array}{c}\text { Zakres } \mathrm{a}_{\mathrm{w}} \\
\mathrm{a}_{\mathrm{w}} \text { range }\end{array}$ & & & & & $\div 0,8$ & & & & \\
\hline
\end{tabular}

Parametr $k$ wyraża stopień interakcji cząsteczek wody znajdujących się w kolejnych warstwach $\mathrm{z}$ adsorbentem. Zgodnie $\mathrm{z}$ wynikami analizy Lewickiego [15] produkty o sigmoidalnym przebiegu izotermy powinny charakteryzować się parametrami modelu GAB: $0,24<k<1$ oraz $5,6<C$, co gwarantuje, że wyznaczona pojemność monowarstwy będzie obarczona błędem mniejszym niż 15,5\%. Badane hydrolizaty spełniały powyższe założenie. 


\section{Wnioski}

1. Izotermy sorpcji pary wodnej hydrolizatów skrobi ziemniaczanej natywnej, acetylowanej oraz fosforanu diskrobiowego charakteryzowały się sigmoidalnym kształtem, odpowiadającym typowi II izoterm zgodnie z klasyfikacją Brunauera i wsp.

2. W punkcie odpowiadającym aktywności wody powyżej 0,7 zaobserwowano wyraźne przegięcie otrzymanych izoterm, oznaczające moment przejścia z zakresu adsorpcji wielowarstwowej do obszaru kondensacji kapilarnej.

3. Zaobserwowano, że właściwości sorpcyjne badanych maltodekstryn zależały głównie od stopnia scukrzenia. Najwyższą higroskopijnością charakteryzowały się hydrolizaty o najwyższej wartości równoważnika glukozowego.

4. Chemiczna modyfikacja skrobi w nieznaczny stopniu wpłynęła na ilość zaadsorbowanej pary wodnej przez hydrolizaty o takim samym DE w I i II zakresie adsorpcji. W środowisku o wysokiej aktywności wody różnice te były znacznie większe.

5. Wartości pojemności monowarstwy wyznaczone z modelu BET były nieznacznie niższe od wartości wyznaczonych z modelu GAB. Niezależnie od rodzaju skrobi poddanej hydrolizie największą pojemność monowarstwy stwierdzono w przypadku maltodekstryn o DE6.

6. Model Pelega umożliwił opisanie danych eksperymentalnych w pełnym badanym zakresie aktywności wody $0,113 \div 0,903$.

Badania sfinansowano z dotacji przyznanej przez MNiSW na działalność statutowa.

\section{Literatura}

[1] Anderson R.B.: Modifications of the B.E.T. equation. J. Am. Chem. Soc., 1946, 68, 686-691.

[2] Al-Muhtaseb A.H., McMinn W.A.M., Magee T.R.A.: Moisture sorption isotherm characteristics of food products: A review. Food Bioprod. Process., 2002, 80 (2), 118-128.

[3] Al-Muhtaseb A.H., McMinn W.A.M., Magee T.R.A.: Water sorption isotherm of starch powders. Part 1: Mathematical description of experimental data. J. Food Eng., 2004, 61, 297-307.

[4] Brunauer S., Deming L.S., Deming W.E., Troller E.: On the theory of Van der Waals adsorption gases. J. Am. Chem. Soc., 1940, 62, 1723-1732.

[5] Brunauer S., Emmett P., Teller E.: Adsorption of gases in multimolecular layers. J. Am. Chem. Soc., 1938, 60, 309-319.

[6] Busch V.M., Pereyra-Gonzalez A., Šegatin N., Santagapita P.R., Ulrih N.P., Buera M.P.: Propolis encapsulation by spray drying: Characterization and stability. LWT-Food Sci. Technol., 2017, 75, 227-235.

[7] Castro N., Durrieu V., Raynaud C., Rouilly A.: Influence of DE-value on the physicochemical properties of maltodextrin for melt extrusion processes. Carbohyd. Polym., 2016, 144, 464-473.

[8] De Boer J.H.: The Dynamical Character of Adsorption. Clarendon Press, Oxford 1953.

[9] Fornal J., Sadowska J., Błaszczak W., Jeliński T., Stasiak M., Molenda M., Hajnos M.: Influence of some chemical modifications on the characteristics of potato starch powders. J. Food Eng., 2012, 108 (4), 515-522. 
[10] Gondek E., Lewicki P.P.: Izotermy sorpcji pary wodnej suszonych i kandyzowanych owoców. Acta Sci. Pol., Technol. Aliment., 2005, 4 (1), 63-71.

[11] Goula A.M., Adamopoulos K.G.: A new technique for spray drying orange juice concentrate. Innov. Food Sci. Emerg., 2010, 11 (2), 342-351.

[12] Guggenheim E.A.: Applications of Statistical Mechanics. Clarendon Press, Oxford 1966.

[13] Karel M.: Water activity and food perservation. In.: Principles and Food Science. Part 2: Physical Principles of Food Perservation. Eds. M. Karel, O.R. Fennema, D.B. Lund. Marcel Dekker, Inc., New York 1975, pp. 237-263.

[14] Leszczyński W.: Zastosowanie skrobi modyfikowanych w przemyśle spożywczym II. Skrobie chemicznie modyfikowane. Przegl. Piek. Cukier., 2006, 6 (55), 6-8.

[15] Lewicki P.P.: The applicability of the GAB model to food water sorption isotherms. Int. J. Food Sci. Technol., 1997, 32, 553-557.

[16] Mishra S., Rai T.: Morphology and functional properties of corn, potato and tapioca starches. Food Hydrocoll.., 2006, 20 (5), 557-566.

[17] Mosquera L.H., Moraga G., Martínez-Navarrete N.: Effect of maltodextrin on the stability of freezedried borojó (Borojoa patinoi Cuatrec.) powder. J. Food Eng., 2010, 97 (1), 72-78.

[18] Pałacha Z, Chrzanowski P.: Badanie procesu adsorpcji i desorpcji wody wybranych skrobi. Post. Techn. Przetw. Spoż., 2013, 1, 58-63.

[19] Peleg M.: Assessment of a semi-empirical four parameter general model for sigmoid moisture sorption isotherms. J. Food Eng., 1993, 16, 21-37.

[20] Phisut N.: Spray drying technique of fruit juice powder: some factors influencing the properties of product. Int. Food Res. J., 2012, 19 (4), 1297-1306.

[21] Pycia K., Juszczak L., Gałkowska D., Witczak M., Jaworska G.: Maltodextrins from chemically modified starches. Selected physicochemical properties. Carbohyd. Polym., 2016, 146, 301-309.

[22] Pycia K., Juszczak L., Socha R.: Maltodextrins from chemically modified starches. Production and characteristics. Starch-Stärke, 2017, doi:10.1002/star.201600199.

[23] Resio A.C., Aguerre R.J., Suarez C.: Analysis of the sorptional characteristics of amaranth starch. J. Food Eng., 1999, 42 (1), 51-57.

[24] Roller S.: Starch-derived Fat Mimetics: Maltodextrins. Handbook of Fat Replacers. CRC Press, New York 1996, pp. 99-118.

[25] Roos Y.: Characterization of food polymers using state diagrams. J. Food Eng., 1995, 24 (3), 339360.

[26] Saavedra-Leos Z., Leyva-Porras C., Araujo-Diaz S., Toxqui-Teran A., Borras-Enriquez A.: Technological application of maltodextrin according to the degree of polymerization. Molecules, 2015, 20, 21067-21081.

[27] Sobolewska-Zielińska J.: Maltodekstryny w przemyśle spożywczym. Laboratorium, 2007, 6, 29-32.

[28] Stępień A., Witczak M., Witczak T., Czader M.: Izotermy sorpcji maltodekstryny przemysłowej o różnym stopniu scukrzenia. Post. Techn. Przem. Spoż., 2015, 2, 51-56.

[29] Timmermann E.O.: Multilayer sorption parameters: BET or GAB values? Colloid Surf. A - Physicochem. Eng. Asp., 2003, 1-3, 235-260.

[30] Wang Y.J., Wang L.: Structures and properties of commercial maltodextrins from corn, potato, and rice starches. Starch-Stärke, 2000, 52 (8-9), 296-304.

\section{EFFECT OF CHEMICAL MODIFICATION OF STARCH AND DEGREE OF HYDROLISIS ON MOISTURE SORPTION ISOTHERMS OF HYDROLYSATES}

\section{S u m m a r y}

In the research study, the moisture sorption isotherms were determined for the hydrolysates obtained by the enzymatic hydrolysis of native potato starch, acetylated potato starch, and distarch phosphate. Furthermore, the effect was determined of the dextrose equivalent values obtained (DE $6,11,16)$ on the 
hygroscopicity of products. The sorption isotherms were determined using a static method in the environment, where water activity ranged from 0 to 0.903 at a temperature of $25^{\circ} \mathrm{C}$. Three mathematical models were applied to describe sorption isotherms. It was found that the four-parameters Peleg's model made it possible to present the experimental data within the full range of water activity while the use of the BET and $\mathrm{GAB}$ models required to limit those data. All the plotted curves were characterized by a sigmoidal shape, typical for isotherms of type II according to the classification by Brunauer et al. [4]. In mono- and multilayer adsorption regions, all the hydrolysates analysed exhibited similar properties. The highest differences in the equilibrium moisture content were reported at a water activity higher than 0.7 . It was found that the sorption properties of the products investigated were determined mainly by the dextrose equivalent values, while the chemical modification of starch significantly impacted the content of adsorbed moisture only in the high water activity environment.

Key words: maltodextrins, dextrose equivalent, modified starch, sorption isotherm 